\author{
Asian Journal of \\ Medical and Biological Research \\ ISSN 2411-4472 (Print) 2412-5571 (Online) \\ www.ebupress.com/journal/ajmbr
}

\title{
Article \\ Effect of fortification of skim milk with coconut milk on the proximate composition and manufacture of dahi, a traditional sweet curd
}

\author{
Md. Rezaul Hai Rakib ${ }^{1 *}$, Morsheda Yesmin ${ }^{2}$, Md. Abu Hemayet ${ }^{1}$, Md. Ahsanul Kabir ${ }^{3}$ and Md. Nurul Islam ${ }^{4}$ \\ ${ }^{1}$ Scientific Officer, Goat and Sheep production Research Division, Bangladesh Livestock Research Institute, \\ Savar, Dhaka-1341, Bangladesh \\ ${ }^{2}$ Scientific Officer, Sheep Project, Bangladesh Livestock Research Institute, Savar, Dhaka-1341, Bangladesh \\ ${ }^{3}$ Scientific Officer, Biotechnology Division, Bangladesh Livestock Research Institute, Savar, Dhaka-1341, \\ Bangladesh \\ ${ }^{4}$ Department of Dairy Science, Bangladesh Agricultural University, Mymensingh-2202, Bangladesh
}

*Corresponding author: Md. Rezaul Hai Rakib, Scientific Officer, Goat and Sheep production Research Division, Bangladesh Livestock Research Institute, Savar, Dhaka-1341, Bangladesh. Mobile: +8801728168861 ; rakib_rezaul@blri.gov.bd

Received: 07 June 2016/Accepted: 22 June 2016/ Published: 30 June 2016

\begin{abstract}
The experiment was conducted to measure the feasibility of partial replacement of skim milk with different levels of coconut milk in the manufacture of dahi. Skimmed milk was replaced by $0,5,10,15$ and $20 \%$ of coconut milk to produce Dahi designated as A, B, C, D and E. All the samples were analyzed for organoleptic, chemical and microbiological qualities. Replacement of skim milk up to $10 \%$ with coconut milk increased total organoleptic score but score decreased when level of coconut milk was $15 \%$ and $20 \%$. Dahi manufactured by incorporating 5\% coconut milk gave superior results for body and consistency and also for colour and texture. In all levels of replacement increased fat, carbohydrates, ash and total solids were obtained, while protein and $\mathrm{pH}$ content were significantly decreased in Dahi samples. Total bacterial count was higher in the dahi manufactured by replacement of coconut milk than control. It could be concluded that 5 and $10 \%$ replacement of skim milk with coconut milk for the manufacturing of Dahi was acceptable and reduced the production cost and they were better in compare to others, according to organoleptic, chemical and microbiological analysis. The work showed the potential of coconut as an alternative source of skim milk in dahi manufacturing with improved nutritional value and consumer acceptability.
\end{abstract}

Keywords: skim milk; coconut milk; dahi; organoleptic

\section{Introduction}

Milk is very nutritious and perhaps an indispensible food for human being. But in this area of industrialization, food habit of common people is changing. They prefer healthier, delicious foods to fresh raw foods. Hence, milk is converted to various products. About $4 \%$ of the total milk produced in Bangladesh is used for the preparation of dahi (Mustafa, 1997). Dahi is the curd resulting from lactic acid fermentation of milk. Fermentation has been an ideal technology to preserve milk from time immemorial. Fermentation of milk by specific microflora accompanying a technological modification and using some additives induces, changes in taste, texture, visual appearance, color, flavor and the nutritive properties of the milk and products a wide variety of foods (Oberman and Libudzisz, 1998). Fermentation also imparts high therapeutic value to the fermented milk products (Adachi, 1992, Yamamoto et al., 1994, Vantycer et al., 1989). Dahi or yoghurt is smooth viscous gel and "nutty" flavoured dairy product resulting from the acidification of milk by fermentation with a mixed lactic starter culture consisting of Streptococcus lactis, Streptococcus thermophilus, Lactobacillus bulgaricus, Streptococcus citrophilus, Lactobacillus plantarum etc. 
Dahi which is prepared from skim milk contain $90-91 \%$ water, $0.05-0.10 \%$ fat, $3.32-3.5 \%$ protein, $4.7-5.3 \%$ lactose, $0.70-0.75 \%$ ash, $0.12-0.14 \%$ calcium and 0.5-1.1\% lactic acid. In Bangladesh dahi is usually prepared from cow and buffalo milk. But, due to lack of milk production it becomes very difficult to maintain regular supply of this product in the market year round. So, skim milk could be an alternative source of milk for the preparation of dairy products. On the other hand, Coconut is highly accepted by the consumer due to its high calorific and nutritive value (3\% protein, $17 \%-24 \%$ fat and $2 \%$ carbohydrate). It has no cholesterol, contains many vitamins, minerals and electrolytes, including potassium, calcium and chloride (Amarasiri and Dissanayake, 2006). It contains a large proportion of lauric acid, a saturated fat that raises blood cholesterol levels by increasing the amount of high-density lipoprotein cholesterol, which is also found in significant amounts in breast milk and sebaceous gland secretions (Amarasiri and Dissanayake, 2006). This may create a more favorable blood cholesterol profile. In this point of view, we can use coconut milk as a fat source as it contains high concentration of vegetable fat. In addition, coconut is very cheap and easily available in our country. Coconut milk is lactose free, unlike cow milk, and can be used as a milk substitute by those with lactose intolerance. Therefore, this research study was aimed to test the feasibility of using skim milk fortified with coconut milk for manufacturing of dahi and also cost effective.

\section{Materials and Methods}

The experiment was carried out at the Dairy Science Laboratory of Bangladesh Livestock Research Institute, Savar, Dhaka and Dairy Technology and Microbiology Laboratory of the Department of Dairy Science, Bangladesh Agricultural University, Mymensingh.

Whole milk was collected from the Bangladesh Agricultural University Dairy Farm, after milking in the morning, which was packed by poly bag. Suggestions were given to the milker's to maintain all hygienic measures like cleaning of udder and utensils etc. To avoid the incorporation of air it was allowed to stand for a while and there after sample was taken in the laboratory for experimental purpose. Skim milk was prepared by the separation of fat from the milk by using the cream separator machine.

Coconuts (Cocos nucifera) were purchased from the local market. The edible portion (cellular endosperm) of coconut was shredded carefully to avoid the waste material. Two cups of warm water $(250 \mathrm{ml})$ for every cup of coconut were used to prepare coconut milk. The coconut and water were blended with high pressure until the mixture was as smooth as possible. When the blending was completed then the coconut milk was filtered by a clean muslin cloth (hot water washed) and kept it in a beaker.

For the preparation of different types of Dahi, either skimmed milk or skim milk samples partially replaced by $5,10,15$ and $20 \%$ of coconut milk were taken in a pan and were heated in boiling temperature to reduce its volume up to $20-25 \%$. During the time of boiling about $12 \%$ sugar was added with each milk sample. At the time of boiling the milk samples were stirred thoroughly by using stirrer and then the milk pans were removed from the heater and allowed to cool down and when the temperature was reached at about $42^{\circ} \mathrm{C}$, then the mixed starter culture was added with each sample at the rate of $2 \%$. Annatto seeds were used as coloring agent. Then the warm milk of $42^{\circ} \mathrm{C}$ was poured into several pre-washed plastic cups after the inoculation and then the Dahi sample were transferred into incubator for coagulation. After 4 hours when the coagulation was completed, then the Dahi samples were taken out from the incubator and the samples were transferred into refrigerator. The refrigerator temperature was $5^{\circ} \mathrm{C}$.

Organoleptic evaluation was performed by eight member expert panel of judges using a 100-point scale (Smell and taste score: 50, body and consistency score: 30, color and texture score: 20).

Chemical analysis (fat, acidity, $\mathrm{pH}$, protein, moisture, carbohydrate, ash) of coconut milk, and skim milk samples were performed before the preparation of Dahi to determine the initial quality. Dahi samples were analyzed chemically for parameters mentioned above. Quevenne lactometer (Kimble Glass Co., USA) was used for the determination of specific gravity of the milk samples (Aggarwala and Sharma, 1961). Total solids and moisture content of the milk samples were estimated by oven (Vulcan A-550 Furnace, USA) drying method (1050C for 24 hours) (AOAC 2003). Babcock method was used for the determination of fat content of reconstituted skimmed milk (Aggarwala and Sharma 1961). The fat content of coconut milk was determined by using ether extract method. Kjeldahl procedure was used for the determination of crude protein. Acidity of milk samples were determined by titration with $0.1 \mathrm{~N} \mathrm{NaOH}$ (Aggarwala and Sharma 1961). The $\mathrm{pH}$ was measured by using a pH meter-215 (Ciba Coming Diagnostics Limited, Suffolk, England Co.). Ash was determined by the incineration method according to AOAC (2003).

To determine the total bacterial count and coliform count of Dahi samples, standard plate count (spc) were performed according to the method as described in the "Standard Methods for Examination of Dairy Products" (APHA 1998). 
Data which were collected from this experiment were subjected to statistical analysis to make difference between treatments. Analysis of variance (ANOVA) was performed to observe the statistical difference between the treatments. All experimental materials were completely homogenous in this experiment. For this reason collected data of this experiment were analyzed by using one way analysis of variance test (CRD) with SPSS statistical package. In case of significant differences least significant difference (LSD) was performed to observe the significant differences within treatment means.

\section{Results and Discussion}

The initial quality of skim milk and coconut milk was determined by conducting different types of chemical analysis in laboratory before preparation of Dahi (Table 1). The average chemical component of the experimental skim milk (Eckles et al. 1951; Raihan 2001; and Rahman 2002) and coconut milk (Law et al. 2009) sample (Table 1) was within normal ranges.

The quality of different types of Dahi sample was analyzed by conducting various organoleptic, chemical and microbiological tests. Organoleptic scores are given in the Table 2. Smell and taste score of Dahi samples having $0,5,10,15$ and $20 \%$ coconut milk were significantly varied $(\mathrm{p}<0.01)$. The highest value was seen in sample ' $\mathrm{C}$ ' followed by 'B', and ' $\mathrm{D}$ ' and the lowest score was recorded in sample 'E'. The variation in smell and taste score of dahi usually depends on type of milk, starter culture and manufacturing process involved (Younus, 1998). There were significant differences $(\mathrm{p}<0.01)$ obtained within the samples for body and consistency score. Highest body and consistency score was seen in the sample 'B' (95\% skim milk $+5 \%$ coconut milk) followed by 'C', 'D' and ' $E$ '. This result agrees with the finding of Altaf (2007). However, statistical analysis showed that there were significant differences $(\mathrm{p}<0.01)$ within the samples for color and texture score. Although the color and texture score of sample ' $\mathrm{B}$ ' is almost similar with ' $\mathrm{C}$ ' but highest score was seen in the sample 'B' (95\% skim milk $+5 \%$ coconut milk) and the lowest score in the sample 'A'. Regarding dahi texture Sakore et al. (2007) advocated the use of stabilizers and additives to improve the textual characteristics of dahi.

There were significant differences $(\mathrm{p}<0.01)$ existed among the overall score of dahi samples. The result of this experiment indicates that by the use of coconut milk total score is decreased up to certain level. Although overall score of sample 'B' (5\% coconut milk) and sample 'C' (10\% coconut milk) of this experiment were little higher than sample 'A' (control) but the scores were within acceptable range. The result of this experiment agrees with the work of Rahman (2002) who found that the addition of fruit juice improved the total score of dahi.

The average acidity percentage and $\mathrm{pH}$ value of dahi samples (A, B, C, D and E) were varied significantly $(\mathrm{p}<0.01)$. Mean percentage of acidity was highest in sample ' $E$ ' and lowest in sample 'A' (Table 3$)$. Acidity increased slightly due to the addition of different levels of coconut milk. This result agrees with the report of Hossain et al. (2008). However, average $\mathrm{pH}$ value was highest in sample 'A' and lowest in sample 'E'. Addition of coconut milk slightly decreased the $\mathrm{pH}$ value of dahi. It is well known that when $\mathrm{pH}$ values decrease then acidity value will increase. Kosikowski (1996) reported that the pH of normal dahi samples should be approximately 4.4 which nearly agree with the present findings.

The total solids content of A, B, C, D and E types of dahi samples are shown in Table 3. Statistical analysis showed that there were significant differences $(\mathrm{P}<0.01)$ within different types of dahi samples for total solids and moisture content. Total solids content was highest in sample ' $E$ ' followed by sample ' $D$ ' and the lowest value was found in the sample 'A' (control). Whereas highest moisture content was seen in sample 'A' (control) and the lowest was in the sample ' $E$ '. Addition of coconut milk increases the total solids content of Dahi. This result also agrees with the report of Hossain et al. (2008). Gupta et al. (1993) said that overall texture was significantly correlated with moisture content.

Fat content of control dahi sample was lower than the dahi with 5, 10, 15 and 20\% coconut milk (Table 3). Significant differences was found for fat content of different types of Dahi samples $(p<0.01)$, whereas there was no significant difference for protein and carbohydrate content among the samples. Highest fat percent was observed in sample 'E' (20\% coconut milk) and lowest was in the sample 'A' (control). Due to high fat content in coconut milk, fat content of different Dahi samples increase with the addition of different levels of coconut milk. Addition of non fat dry milk and vegetable oil also improve the total solids, fat and protein content of Dahi samples (Munzur et al. 2004). This result also agrees with the finding of Hossain et al. (2008). On the other hand, the value of ash content of different Dahi samples (A, B, C and D) were statistically significant $(\mathrm{p}<0.01)$ and it was observed that ash value increased gradually due to the addition of different levels of coconut milk which agrees with the result obtained by Mustafa (1997), Yasmin (1999), Desai et al. (1994) and Altaf (2007). 
The average total viable count $\mathrm{cfu} / \mathrm{ml}$ of Dahi samples were listed in Table 4. Statistical analysis showed that there was significant $(\mathrm{p}<0.01)$ differences among the different types of Dahi samples. Highest total viable count $/ \mathrm{ml}$ was recorded for ' $\mathrm{E}$ ' type dahi sample and lowest value was recorded for 'A' type dahi. The result of present study nearly agrees with the findings of Altaf (2007). However, there was no existence of any coliform bacteria in any Dahi samples. The presence of coliform bacteria indicates unhygienic conditions of Dahi preparation. Coliform bacteria are usually present in fecal materials contaminated water and feed stuffs used for livestock feeding. In the present study, to avoid contamination strict hygienic measures were taken.

Cost analysis of different types of dahi prepared in the laboratory was presented in Table 5.

The production cost for per kg laboratory made 'A' type (control) dahi is 61Tk., 'B' type (5\% coconut milk) is 59.5 Tk., 'C' type (10\% coconut milk) is $58 \mathrm{Tk}$., 'D' type (15\% coconut milk) is 56.5 Tk., 'E' type (20\% coconut milk) $55 \mathrm{Tk}$. So, in comparison to laboratory made Dahi, benefit for per kg 'B' type dahi was 1.5 taka, benefit for per $\mathrm{kg}$ 'C' type dahi was 3 taka, benefit for per $\mathrm{kg}$ ' $\mathrm{D}$ ' type dahi was 4.5 taka and benefit for per $\mathrm{kg}$ `E' type dahi was 6 taka.

Table 1. Chemical composition of experimental skim milk and coconut milk sample.

\begin{tabular}{|c|c|c|c|c|c|c|c|c|c|}
\hline \multirow{2}{*}{$\begin{array}{l}\text { Sample } \\
\text { type }\end{array}$} & \multirow{2}{*}{$\begin{array}{l}\text { Specific } \\
\text { Gravity }\end{array}$} & \multirow[t]{2}{*}{ Acidity \% } & \multirow{2}{*}{ pH value } & \multicolumn{2}{|c|}{ Total solids Fat } & \multirow[t]{2}{*}{ SNF } & \multirow{2}{*}{$\begin{array}{l}\text { Protein } \\
/ \mathbf{k g})\end{array}$} & \multicolumn{2}{|c|}{$\begin{array}{l}\text { Lactose or Ash } \\
\text { CHO }\end{array}$} \\
\hline & & & & & & & & & \\
\hline$\overline{\mathrm{SM}}$ & $1.034 \pm 0.0006$ & $0.145 \pm 0.05$ & $6.76 \pm 0.02$ & $86.7 \pm 1.1$ & $3.67 \pm 0.88$ & $82.35 \pm 1.85$ & $33.7 \pm 1.3$ & $41.42 \pm 2.74$ & $7.23 \pm 0.09$ \\
\hline CM & $1.008 \pm 0.0001$ & $0.13 \pm 0.01$ & $6.4 \pm 0.01$ & $291.05 \pm 3.0$ & $210.0 \pm 11.0$ & $81.0 \pm 8.0$ & $22.0 \pm 5.0$ & $52.3 \pm 4.5$ & $7.0 \pm 3.0$ \\
\hline
\end{tabular}

SM, skimmed milk; CM, coconut milk

Table 2. Organoleptic parameters of Dahi prepared from skimmed milk and its partial replacement with coconut milk.

\begin{tabular}{|c|c|c|c|c|c|c|c|}
\hline \multirow{2}{*}{ Parameters } & \multicolumn{5}{|c|}{ Treatment } & \multirow{2}{*}{$\begin{array}{l}\text { LSD } \\
\text { value }\end{array}$} & \multirow{2}{*}{$\begin{array}{l}\text { Level } \\
\text { of sig. }\end{array}$} \\
\hline & $\mathbf{A}$ & $\mathbf{B}$ & $\mathbf{C}$ & D & $\mathbf{E}$ & & \\
\hline $\begin{array}{l}\text { Smell and Taste } \\
(50)\end{array}$ & $41.33^{\mathrm{b}} \pm 1.15$ & $42.67^{\mathrm{ab}} \pm 0.58$ & $44.33^{\mathrm{a}} \pm 1.15$ & $41.00^{\mathrm{b}} \pm 1.00$ & $37.33^{\mathrm{c}} \pm 2.08$ & 1.36 & $* *$ \\
\hline $\begin{array}{l}\text { Body and texture } \\
\text { (30) }\end{array}$ & $23.67^{b c} \pm 0.58$ & $26.00^{\mathrm{a}} \pm 1.73$ & $25.00^{\mathrm{ab}} \pm 1.00$ & $23.33^{\mathrm{bc} \pm} 0.58$ & $22.33^{c}+0.58$ & 1.22 & $* *$ \\
\hline $\begin{array}{l}\text { Color and } \\
\text { appearance (20) }\end{array}$ & $13.67^{\mathrm{c}} \pm 0.58$ & $17.00^{\mathrm{a}} \pm 1.00$ & $16.00^{\mathrm{ab}} \pm 1.00$ & $14.67^{b c} \pm 1.15$ & $14.00^{\mathrm{c}} \pm 1.00$ & 1.01 & $* *$ \\
\hline Total score (100) & $74.41^{\mathrm{c}} \pm 1.17$ & $85.53^{\mathrm{a}} \pm 1.91$ & $80.99^{b} \pm 2.34$ & $74.67^{\mathrm{cd}} \pm 3.75$ & $72.22^{\mathrm{d}} \pm 2.34$ & 3.500 & $* *$ \\
\hline
\end{tabular}

A: $100 \%$ skimmed milk; B: $5 \%$ coconut milk; C: $10 \%$ coconut milk; D: $15 \%$ coconut milk; E: $20 \%$ coconut milk; Means with different superscripts in the same row differed significantly; * = Significant at $5 \%$ level $(\mathrm{p}<0.05) ; * *=$ Significant at $1 \%$ level $(\mathrm{p}<0.01)$

Table 3. Chemical parameters of Dahi prepared from skimmed milk and its partial replacement with coconut milk.

\begin{tabular}{|c|c|c|c|c|c|c|c|}
\hline \multirow{2}{*}{ Parameters } & \multicolumn{5}{|c|}{ Treatment } & \multirow{2}{*}{$\begin{array}{l}\text { LSD } \\
\text { value }\end{array}$} & \multirow{2}{*}{$\begin{array}{l}\text { Level of } \\
\text { sig. }\end{array}$} \\
\hline & $\mathbf{A}$ & B & $\mathrm{C}$ & D & $\mathbf{E}$ & & \\
\hline Acidity (\%) & $0.71^{c} \pm 0.049$ & $0.73^{b c} \pm 0.009$ & $0.74^{\mathrm{bc}} \pm 0.21$ & $0.76^{\mathrm{ab}} \pm 0.022$ & $0.79^{a} \pm 0.022$ & 0.218 & $* *$ \\
\hline $\mathrm{pH}$ value & $4.53^{\mathrm{a}} \pm 0.010$ & $4.43^{\mathrm{ab}} \pm 0.16$ & $4.33^{b c} \pm 0.20$ & $4.23^{\mathrm{cd}} \pm 0.22$ & $4.15^{\mathrm{d}} \pm 0.31$ & 0.058 & $* *$ \\
\hline Total solids $(\mathrm{g} / \mathrm{kg})$ & $221.25^{\mathrm{d}} \pm 9.33$ & $237.13^{\mathrm{c}} \pm 3.65$ & $249.05^{\mathrm{b}} \pm 4.16$ & $263.88^{\mathrm{a}} \pm 7.63$ & $272.93^{\mathrm{a}} \pm 4.98$ & 6.65 & $* *$ \\
\hline Moisture $(\mathrm{g} / \mathrm{kg})$ & $782.47^{\mathrm{a}} \pm 0.75$ & $765.27^{\mathrm{b}} \pm 2.66$ & $746.64^{\mathrm{c}} \pm 5.47$ & $739.06^{c} \pm 8.91$ & $731.38^{c} \pm 5.90$ & 9.60 & $* *$ \\
\hline Fat $(\mathrm{g} / \mathrm{kg})$ & $2.2^{\mathrm{e}} \pm 0.11$ & $14.0^{\mathrm{d}} \pm 0.10$ & $25.8^{\mathrm{c}} \pm 0.13$ & $40.4^{\mathrm{b}} \pm 0.61$ & $49.3^{\mathrm{a}} \pm 0.25$ & 3.24 & $* *$ \\
\hline Protein $(\mathrm{g} / \mathrm{kg})$ & $35.3 \pm 0.667$ & $34.92 \pm 0.729$ & $34.53 \pm 0.833$ & $34.13 \pm 0.814$ & $33.71 \pm 0.973$ & - & NS \\
\hline Carbohydrate (g/kg) & $176.67 \pm 8.977$ & $181.0 \pm 2.606$ & $181.530 \pm 1.353$ & $181.83 \pm 2.084$ & $182.60 \pm 1.800$ & - & NS \\
\hline $\operatorname{Ash}(g / k g)$ & $7.0^{\mathrm{e}} \pm 0.490$ & $7.3^{\mathrm{d}} \pm 0.086$ & $7.42^{c} \pm 0.202$ & $7.57^{\mathrm{b}} \pm 0.219$ & $787^{\mathrm{a}} \pm 0.306$ & 0.218 & $* *$ \\
\hline
\end{tabular}

A: $100 \%$ skimmed milk; B: $5 \%$ coconut milk; C: $10 \%$ coconut milk; D: $15 \%$ coconut milk; E: $20 \%$ coconut milk; Means with different superscripts in the same row differed significantly; $*=$ Significant at $5 \%$ level $(\mathrm{p}<0.05) ; * *=$ Significant at $1 \%$ level $(\mathrm{p}<0.01) \mathrm{NS}=$ Non Significant 
Table 4. Microbiological parameters of Dahi prepared from skimmed milk and its partial replacement with coconut milk.

\begin{tabular}{|c|c|c|c|c|c|c|c|c|}
\hline \multirow{2}{*}{\multicolumn{2}{|c|}{ Parameters }} & \multicolumn{5}{|c|}{ Treatment } & \multirow{2}{*}{$\begin{array}{l}\text { LSD } \\
\text { value }\end{array}$} & \multirow{2}{*}{$\begin{array}{l}\text { Level } \\
\text { of sig. }\end{array}$} \\
\hline & & A & B & C & D & $\mathbf{E}$ & & \\
\hline $\begin{array}{l}\text { Total viable } \\
\text { (CFU/ml) }\end{array}$ & count & $82.67^{b} \times 10^{4}$ & $85.67^{\mathrm{ab}} \times 10^{4}$ & $84.67^{\mathrm{ab}} \times 10^{4}$ & $91.00^{\mathrm{a}} \times 10^{4}$ & $94.67^{\mathrm{a}} \times 10^{4}$ & 25.34 & $* *$ \\
\hline $\begin{array}{l}\text { Coliform } \\
\text { (CFU/ml) }\end{array}$ & count & Nil & Nil & Nil & Nil & Nil & - & - \\
\hline
\end{tabular}

A: $100 \%$ skimmed milk; B: $5 \%$ coconut milk; C: $10 \%$ coconut milk; D: $15 \%$ coconut milk; E: $20 \%$ coconut milk; Means with different superscripts in the same row differed significantly; $*=$ Significant at $5 \%$ level $(\mathrm{p}<0.05)$; $* *=$ Significant at $1 \%$ level $(\mathrm{p}<0.01) \mathrm{NS}=$ Non Significant; CFU=Colony Forming Unit

Table 5. Cost (BDT) for different types of dahi prepared in the laboratory.

\begin{tabular}{|c|c|c|c|c|c|c|}
\hline Items & Amount & $\mathbf{A}$ & B & $\mathbf{C}$ & D & $\mathbf{E}$ \\
\hline \multirow{5}{*}{ Cow milk } & $400 \mathrm{ml}$ & 12 & & & & \\
\hline & $380 \mathrm{ml}$ & & 11 & & & \\
\hline & $360 \mathrm{ml}$ & & & 10 & & \\
\hline & $340 \mathrm{ml}$ & & & & 9 & \\
\hline & $320 \mathrm{ml}$ & & & & & 8 \\
\hline \multirow{4}{*}{ Coconut Milk } & $20 \mathrm{ml}$ & & 0.4 & & & \\
\hline & $40 \mathrm{ml}$ & & & 0.8 & & \\
\hline & $60 \mathrm{ml}$ & & & & 1.2 & \\
\hline & $80 \mathrm{ml}$ & & & & & 1.6 \\
\hline Sugar & $40 \mathrm{~g}$ & 2.4 & 2.4 & 2.4 & 2.4 & 2.4 \\
\hline Starter & $8 \mathrm{~g}(2 \%)$ & 0.5 & 0.5 & 0.5 & 0.5 & 0.5 \\
\hline Plastic cup & 6 pieces & 4.5 & 4.5 & 4.5 & 4.5 & 4.5 \\
\hline Cost for Electricity & $0.4 \mathrm{~kg}$ & 1.0 & 1.0 & 1.0 & 1.0 & 1.0 \\
\hline Cost for fuel & $0.4 \mathrm{~kg}$ & 1.0 & 1.0 & 1.0 & 1.0 & 1.0 \\
\hline Labor cost & $0.4 \mathrm{k}$ & 1.0 & 1.0 & 1.0 & 1.0 & 1.0 \\
\hline Depreciation cost & $0.4 \mathrm{~kg}$ & 1.0 & 1.0 & 1.0 & 1.0 & 1.0 \\
\hline \multicolumn{2}{|c|}{ Cost minimum for $0.4 \mathrm{~kg}$ Dahi } & 23.4 & 22.8 & 22.2 & 21.6 & 21 \\
\hline \multicolumn{2}{|c|}{ Cost minimum for $1 \mathrm{~kg}$ Dahi } & 58.5 & 57 & 55.5 & 54 & 52.5 \\
\hline \multicolumn{2}{|c|}{ Vat $(1.5 \%)$} & 1.0 & 1.0 & 1.0 & 1.0 & 1.0 \\
\hline \multicolumn{2}{|l|}{ Transportation cost } & 1.5 & 1.5 & 1.5 & 1.5 & 1.5 \\
\hline \multicolumn{2}{|c|}{ Total cost of production for $1 \mathrm{~kg}$ dahi } & 61 & 59.5 & 58 & 56.5 & 55 \\
\hline
\end{tabular}

A: $100 \%$ skimmed milk; B: $5 \%$ coconut milk; C: $10 \%$ coconut milk; D: $15 \%$ coconut milk; E: $20 \%$ coconut milk

\section{Conclusions}

The results from this experiment showed that there was an increase in total solids and fat content of dahi as the inclusion level of coconut milk increased. The indication from this study therefore showed the possibility of using a milk analogue from a vegetable source, such as coconut, in dahi manufacturing. On the basis of organoleptic, chemical and microbiological tests it was concluded that 5\% replacement of skim milk with coconut milk scored highest but $10 \%$ replacement of skim milk with coconut milk are also within the acceptable range for the manufacturing of Dahi and both were reduced the production cost. Addition of coconut milk with skim milk not only enriches the nutritive value of dahi, but also it makes the products cheaper in comparison with skim milk (control) dahi. If these types of dahi are introduced in commercial sector, it might be chosen by the consumers and demand load on whole milk dahi would be reduced.

\section{Conflict of interest}

None to declare. 


\section{References}

Adachi S, 1992. Lactic acid bacteria and tumor control in lactic acid bacteria in health and disease. Edited By B. J. B. Wood Elsevier Applied Science, 233-261.

Aggarwala AC and Sharma, 1961. A Laboratory manual of milk Inspection. $4^{\text {th }}$ edition Asia Publishing House, Bombay, Calcutta, New Delhi, India.

Altaf, 2007. Preparation of dahi from cow milk with the addition of different levels of coconut milk. M.S. thesis, Dept. of Dairy Science, Bangladesh Agricultural University, Mymensingh.

Amarasiri WA and AS Dissanayake, 2006. Coconut fats. Ceylon Medical Journal, 51: 47-51.

AOAC, 2003. Official Methods of Analysis (17.ed.). Association of official Agriculture Chemistry. Washington, D.C.

APHA (American Public Health Association), 1998. Standard Methods for Examination of Dairy Products $20^{\text {th }}$ edn. Washington. D. C.

Desai SR, VA Toro and S Joshi, 1994. Utilization of different fruits in the manufacture of yoghurt. Indian Journal of Dairy Science, 47: 870-874.

Eckles C, HHP Combs and H Hacy, 1951. Milk and Milk Products. 41h edition. Mcgraw- Hill Book Company, New York, Toronto London, 48.

Gupta SK, GR Patil, HK Desai and BC Ghosh, 1993. Texture studies on selected Indian Dairy Products: composition, texture relationship. International Dairy Journal, 5: 234-240.

Hossain MA, A Wadud, MAS Khan, MA Islam and A Matubbar, 2008. Preparation of Dahi from cow milk adding of coconut milk. Bangladesh Journal of Progressive Science and Technology, 6: 345-348.

Kosikowski F, 1996. Cheese and fermented milk products. Published by the author, Ithaca, New York.

Law HY, CI Ong, NA Aziz, FS Taip and Muda, 2009. Preliminary work on coconut milk fouling deposits study. International Journal of Engineering \& Technology, 9: 10.

Munzur MM, MN Islam, S Akhter and MR Islam, 2004. Effect of different levels of vegetable oil for the manufacture of dahi from skim milk. Asian Australasian Journal of Animal Science, 17: 1019-1025.

Mustafa MMH, 1997. A study on the preparation of fruit dahi (yoghurt). M. S. Thesis Department of Dairy Science, Bangladesh Agricultural University, Mymensingh.

Oberman H and Z Libudzisz, 1998. Physiological activity of Str. diacetilactis and Lact. casei strains in continuous culture system. Acta Alimentaria polorica. microbiology of fermented Foods. Vol. IEd.Brain. J. B. Wood Blackie Academi and professional, Madras, 308-350.

Rahman M, 2002. A comparative study on cows and buffaloes milk and their shelf-life at room and refrigeration temperature. M. S. Thesis, Department of Dairy Science, Bangladesh Agricultural University Mymensingh.

Raihan H, 2001. Study on acidophilus dahi prepared from cow milk and powderd milk. M.S. Thesis, Department of Dairy Science, Bangladesh Agricultural University, Mymensingh.

Sakore DB, PT Dhole, KD Chavan and BK Pawar, 2007. Role and vialibility of probiotic cultures in cow milk dahi. Indian Journal of Dairying Foods and Home Sciences, 26: 63-68.

Vantycer P, JM Dekker, MJW Lamers, FJ Kok, EG Schoun, HAM Brants, F Sterimans and RJJ Herineus, 1989. Consumption of fermented milk products and breast cancer: a case study in the Netherlands. Cancer Research 49: 4020-30.

Yamamoto N, A Akino and T Takano, 1994. Antihypertensive effects of different kinds of fermented milk in spontaneously hypertensive rats. Biosciences, Biotechnology and Biochemistry, 58: 77-86.

Yasmin N, 1999. Utilization of mango (Mangifera Indiaca) Juice for preparation of yoghurt. M. S. Thesis, Department of Dairy Science, Bangladesh Agricultural University, Mymensingh.

Younus M, 1998. A comparative study on the quality ofs dahi (yogurt) available in Mymensingh Town. M. S. Thesis, Department of Dairy Science, Bangladesh Agricultural University, Mymensinsgh. 